\title{
The effect of crossing of Corriedale type ewes with prolific rams on the wool productivity of their progeny*
}

\author{
R. Niżnikowski, W. Janikowski and W. Rant \\ Institute of Animal Breeding and Technology of Animal Production \\ Warsaw Agricultural University - SGGW \\ 05-840 Brwinów, Poland
}

(Received 25 November 1991; accepted I June 1992)

\begin{abstract}
The experiment was carried out from 1982 to 1989 on 318 Corricdale ewes on their $F_{1}$ crosses with prolific rams i.e. East Friesian, Finnish and Polish „Wrzosowka”. The following traits were analyzed: wool production and staple length at the age of 12 months, wool production at the age of 2 , 3,4 , and 5 years, and fleece quality of two-tootched ewes.

The progeny of Corriedale type ewes crossed with prolific rams had decreased $(P \leqslant 0.01)$ wool production, e. g. the lowest fleece weight and increased staple length and wool thickness was found in the progeny descended from the Polish, Wrzosówka" rams. Crossing decreased $(P \leqslant 0.01)$ the fleece quality (according to the appraisal method) in the progeny of Finnish and Polish "Wrzosówka" rams. However, the fleeces of the progeny of Friesian rams were better $(P \leqslant 0.01)$ than those of the control group.
\end{abstract}

KEY WORDS: sheep, commercial crossing, wool production

\section{INTRODUCTION}

The $F_{1}$ progeny of ewes crossbred with prolific rams showes altered reproduction traits (Borys and Osikowski, 1986; Gut et al., 1986; Śliwa et al., 1983; Wassmuth and Jatsch, 1980) and wool production (Borys et al., 1986; Süss and König, 1984; Śliwa et al., 1983). Some experiments have shown that crossing of Polish Merino ewes with prolific rams increases the wool production and fibre thickness in their progeny (Borys et al., 1986; Borys and Stankiewicz, 1986; Gut

* The experiment was conducted within the framework of project PR.II.21, coordinated by the Agricultural Academy in Poznan (Poland) 
et al., 1986; Süss and König, 1984). However, only one experiment on a Lowland sheep has been carried out (Wielkopolska variety ewes mated to prolific rams) and it has shown that $F_{1}$ progeny is characterized by a lower quantity of wool in comparison to Wielkopolska ewes (Gut et al., 1986). Due to the fact that the Corriedale type ewes have not been evaluated in respect to commercial crossing, a comparison of wool production of $F_{1}$ crossbreds with prolific rams is presented.

\section{MATERIAL AND METHODS}

The experiment was carried out on ewes kept on the farm belonging to the Warsaw Agricultural University Experimental Station in Puczniew-Mianów. The following breed types were evaluated: Corriedale (Cor), $\mathrm{F}_{1}$ \& Corriedale $x \delta$ East Friesian $(\mathrm{CxEF}), \mathrm{F}_{1} q$ Corriedale $\mathrm{x} \partial$ Finnish $(\mathrm{CxF})$ and $\mathrm{F}_{1}$ o Corriedale x $\delta$ Polish „Wrzosówka" (CxPW). The ewes were born between 1982 and 1987. They were kept in equal environmental conditions, in a barn with bedding, throughout the year. The animals were fed according to the Polish standards (Ryś, 1974). They were shorn annually at the end of the year. The following traits were analyzed: staple length and wool production at the age of 12 months, 2, 3, 4 and 5 years. Additionally, fleeces of 2 year old ewes, born between 1982 and 1987, were assessed by the Laboratory of Fleece Evaluation in Łódź by a touch and see methods (Skoczylas, 1963).

The least squares method was used for the statistical analysis (Harvey, 1987). The following statistical model for the staple length and wool production at the age of 1 and 2 years was used:

$$
\mathrm{Y}_{\mathrm{ijk}}=\mu+\mathrm{a}_{\mathrm{i}}+\mathrm{b}_{\mathrm{j}}+(\mathrm{ab})_{\mathrm{ij}}+\mathrm{e}_{\mathrm{ijk}} \text {, }
$$

where:

$$
\begin{array}{ll}
Y_{i j k} & - \text { analyzed traits } \\
\mu & - \text { mean } \\
a_{i} & - \text { influence of age }(i=1982, \ldots, 1987) \\
b_{j} & \text { - influence of breed type }(j=\text { Cor, CxEF, CxF, CxPW }) \\
(a b)_{i j k} & - \text { influence of an interaction } \\
e_{i j k} & - \text { remaining factors }
\end{array}
$$

Analyses of wool production at the age of 3,4 and 5 years also included the number of sucking lambs into the model: 


$$
\mathrm{Y}_{\mathrm{ijk}}=\mu+\mathrm{a}_{\mathrm{i}}+\mathrm{b}_{\mathrm{j}}+(\mathrm{ab})_{\mathrm{ij}}+\mathrm{b}\left(\mathrm{x}_{1}-\mathrm{x}\right)+\mathrm{e}_{\mathrm{ijk}}
$$

where:

$b\left(x_{1}-x\right)-$ influence of regression as to the number of sucking lambs.

The first model was also used to analyze the number of points given for each fleece during the appraisal at the Laboratory of Fleece Evaluation. When the influence of the breed type was significant, the Duncan test was used (Ruszczyc, 1981). In respect to the number of fleeces classified to either the upper or the lower category, differences between these groups were evaluated using the $\chi^{2}$ test (Ruszczyc, 1981). The fleeces were also classified according to the content of fibres in different thickness groups.

\section{RESULTS AND DISCUSSION}

The influence of the breed type is given in Table 1. The highest staple length at

TABLE 1

The influence of the breed type on fleece weight $(\mathrm{kg})$ and staple length $(\mathrm{cm})$

\begin{tabular}{|c|c|c|c|c|c|}
\hline Parameter & & Cor & $\mathrm{CxEF}$ & $\mathrm{CxF}$ & $\mathrm{CxPW}$ \\
\hline $\begin{array}{l}\text { Staple iength at the age } \\
\text { of } 12 \mathrm{mths} .(\mathrm{cm})\end{array}$ & $\begin{array}{c}\frac{n}{x} \\
S_{E}\end{array}$ & $\begin{array}{r}100 \\
9.52^{A} \\
0.24\end{array}$ & $\begin{array}{c}60 \\
10.37^{\mathrm{B}} \\
0.22\end{array}$ & $\begin{array}{c}56 \\
10.77^{\mathrm{B}} \\
0.24\end{array}$ & $\begin{array}{c}58 \\
12.16^{\mathrm{C}} \\
0.27\end{array}$ \\
\hline $\begin{array}{l}\text { Fleece weight at the age } \\
\text { of } 12 \mathrm{mths} .(\mathrm{kg})\end{array}$ & $\begin{array}{c}\frac{n}{x} \\
S_{E}\end{array}$ & $\begin{array}{c}91 \\
4.15^{\wedge} \\
0.13\end{array}$ & $\begin{array}{c}78 \\
3.36^{\mathbf{B}} \\
0.09\end{array}$ & $\begin{array}{c}77 \\
3.28^{\mathrm{B}} \\
0.10\end{array}$ & $\begin{array}{c}72 \\
2.98^{\mathrm{C}} \\
0.11\end{array}$ \\
\hline $\begin{array}{l}\text { Fleece weight at the age } \\
\text { of } 2 \text { years }(\mathrm{kg})\end{array}$ & $\begin{array}{l}\frac{n}{x} \\
S_{t}\end{array}$ & $\begin{array}{r}105 \\
5.75^{\mathrm{A}} \\
0.13\end{array}$ & $\begin{array}{c}70 \\
4.89^{\mathrm{B}} \\
0.10\end{array}$ & $\begin{array}{c}68 \\
4.49^{\mathrm{C}} \\
0.11\end{array}$ & $\begin{array}{c}69 \\
4.12^{\mathrm{D}} \\
0.12\end{array}$ \\
\hline $\begin{array}{l}\text { Fleece weight at the age } \\
\text { of } 3 \text { years }(\mathrm{kg})\end{array}$ & $\begin{array}{l}\frac{n}{x} \\
S_{E}\end{array}$ & $\begin{array}{r}100 \\
5.17^{\mathrm{A}} \\
0.13\end{array}$ & $\begin{array}{c}53 \\
4.30^{\mathrm{B}} \\
0.11\end{array}$ & $\begin{array}{c}42 \\
4.13^{\mathrm{Ca}} \\
0.13\end{array}$ & $\begin{array}{c}40 \\
3.84^{C b} \\
0.15\end{array}$ \\
\hline $\begin{array}{l}\text { Flcece weight at the age } \\
\text { of } 4 \text { years }(\mathrm{kg})\end{array}$ & $\begin{array}{l}n \\
\bar{x} \\
S_{E}\end{array}$ & $\begin{array}{c}85 \\
5.08^{\wedge} \\
0.11\end{array}$ & $\begin{array}{c}34 \\
4.10^{\mathrm{Ca}} \\
0.12\end{array}$ & $\begin{array}{c}28 \\
4.36^{\mathrm{B}} \\
0.15\end{array}$ & $\begin{array}{c}29 \\
3.75^{\mathrm{cb}} \\
0.15\end{array}$ \\
\hline $\begin{array}{l}\text { Fleece weight at the age } \\
\text { of } 5 \text { years }(\mathrm{kg})\end{array}$ & $\begin{array}{l}\frac{n}{x} \\
S_{E}\end{array}$ & $\begin{array}{c}65 \\
5.45^{\mathrm{A}} \\
0.12\end{array}$ & $\begin{array}{c}19 \\
4.27^{\mathrm{B}} \\
0.16\end{array}$ & $\begin{array}{c}11 \\
4.03^{\mathrm{B}} \\
0.23\end{array}$ & $\begin{array}{c}18 \\
3.93^{\mathrm{B}} \\
0.18\end{array}$ \\
\hline
\end{tabular}

$a, b-P \leqslant 0.05$;

A, B, C, D - P $\leqslant 0.01$ 
the age of 12 months was found in $\mathrm{CxPW}$, while the lowest in Cor. Both groups differed significantly $(\mathrm{P} \leqslant 0.01)$ between themselves. The $\mathrm{CxEF}$ and $\mathrm{CxF}$ did not differ between themselves but did differ $(P \leqslant 0.01)$ from Cor and CxPW. Wool production was significantly higher $(P \leqslant 0.01)$ at the age of 12 months, 3 and 4 years in the Cor group. The CxPW group was characterized by the lowest $(\mathrm{P} \leqslant 0.01)$ wool production. As in the case of staple length, the $\mathrm{CxEF}$ and $\mathrm{CxF}$ groups were in a central position and differed $(\mathrm{P} \leqslant 0.01)$ from the other groups. Analysis of wool production at the age of 2 years showed differences among the groups. The highest $(\mathrm{P} \leqslant 0.01)$ production was observed in the Cor group, then $\mathrm{CxEF}, \mathrm{CxF}$ and $\mathrm{CxPW}$. The highest wool production at the age of 5 years was also observed in the Cor group. This group significantly differed $(\mathrm{P} \leqslant 0.01)$ from the other groups.

The results given above point to a decreased wool production and higher staple length in $F_{1}$ progeny descended from the prolific rams as compared with Cor. The extreme values were observed in the CxPW group. The results of this experiment were similar to those obtained by Sliwa et al. (1983) who have crossed East Friesian rams with Wielkopolska sheep. Our results differ, however, from those given by Borys et al. (1986), Borys and Stankiewicz (1986), Süss and König (1984) concerning the progeny of East Friesian and Finnish rams mated to Polish Merino ewes.

The influence of the mother's genotype on the wool quality traits of their daughters at the age of 2 years is given in Table 2. The significance of differences among the groups in respect to wool weight and staple length were similar to that in 2 year-old ewes (fleece weight) and 12 month-old ewes (staple length). These results were described with those presented in Table 1 . The highest $(P \leqslant 0.01)$ clean wool yield was observed in Cor and the lowest $(\mathrm{P} \leqslant 0.01)$ in $\mathrm{CxF}$ and $\mathrm{CxPW}$. The CxEF placed in the middle. All of the differences were significant $(P \leqslant 0.01)$. Evaluation of wool yield showed that the highest $(P \leqslant 0.01)$ yields were in the CxEF and CxPW groups and the lowest in $\mathrm{CxF}$. The highest $(P \leqslant 0.01)$ content of fleece offals was observed in group $\mathrm{CxPW}$. The wool quality in each group was also evaluated. The results were as follows: Cor -63 's, $\mathrm{CxEF}$ and $\mathrm{CxF}$ -56 's/50's and for CxPW - 48's. These results show the influence of the Polish „Wrzosówka" rams on wool quality.

The number of fleeces classified as either the upper or the lower grade showed that the Cor and $\mathrm{CxEF}$ groups had the best $(\mathrm{P} \leqslant 0.01)$ fleeces and CxPW the worst. This results is similar to that of fleece offals content, where the highest $(\mathrm{P} \leqslant 0.01)$ content of the offals was observed in the group CxPW.

The results of evaluation of fleeses are given in Table 3. Average wool quality was similar in all of the groups. The highest $(P \leqslant 0.01)$ strength and wool yields were observed in groups Cor and $\mathrm{CxEF}$, the highest $(\mathrm{P} \leqslant 0.01)$ elasticity of wool in $\mathrm{CxEF}$ and $\mathrm{CxF}$. The best $(\mathrm{P} \leqslant 0.01)$ conformation of length was observed in 
TABLE 2

The influence of breed type on some fleece traits and wool quality of two-tooth ewes

\begin{tabular}{|l|c|c|c|c|c|}
\hline Parameter & & Cor & CxEF & CxF & CxPW \\
\hline Number of animals & $\mathrm{n}$ & 104 & 70 & 71 & 70 \\
\hline Fleece weight (kg) & $\overline{\mathrm{x}}$ & $5.28^{\mathrm{A}}$ & $4.82^{\mathrm{B}}$ & $4.39^{\mathrm{C}}$ & $4.01^{\mathrm{D}}$ \\
& $\mathrm{S}_{\mathrm{E}}$ & 0.17 & 0.10 & 0.11 & 0.11 \\
\hline Clean wool weight (kg) & $\overline{\mathrm{x}}$ & $2.98^{\mathrm{A}}$ & $2.79^{\mathrm{B}}$ & $2.40^{\mathrm{C}}$ & $2.32^{\mathrm{C}}$ \\
& $\mathrm{S}_{\mathrm{E}}$ & 0.11 & 0.06 & 0.07 & 0.07 \\
\hline Wool yield (kg) & $\overline{\mathrm{x}}$ & $56.31^{\mathrm{AB} u}$ & $57.44^{\mathrm{Ab}}$ & $54.33^{\mathrm{C}}$ & $57.56^{\mathrm{A}}$ \\
& $\mathrm{S}_{\mathrm{F}}$ & 0.66 & 0.38 & 0.42 & 0.42 \\
\hline Offals weight (kg) & $\overline{\mathrm{x}}$ & 0.28 & 0.27 & 0.23 & 0.25 \\
& $\mathrm{~S}_{\mathrm{E}}$ & 0.02 & 0.01 & 0.01 & 0.01 \\
\hline Offals content (\%) & $\overline{\mathrm{x}}$ & $5.59^{\mathrm{A}}$ & $5.37^{\mathrm{A}}$ & $5.27^{\mathrm{A}}$ & $7.79^{\mathrm{B}}$ \\
\hline Staple length (cm) & $\mathrm{S}_{\mathrm{E}}$ & 0.36 & 0.44 & 0.49 & 0.49 \\
\hline Upper class (\%) & $\overline{\mathrm{x}}$ & $10.69^{\mathrm{A}}$ & $11.63^{\mathrm{B}}$ & $11.95^{\mathrm{B}}$ & $14.14^{\mathrm{C}}$ \\
\hline Lower class (\%) & $\mathrm{S}_{\mathrm{E}}$ & 0.49 & 0.28 & 0.31 & 0.31 \\
\hline Wool quality (\%) & $\overline{\mathrm{x}}$ & $94.23^{\mathrm{A}}$ & $91.43^{\mathrm{A}}$ & $60.56^{\mathrm{B}}$ & $37.14^{\mathrm{C}}$ \\
\hline 60 's & $\overline{\mathrm{x}}$ & $5.77^{\mathrm{A}}$ & $8.57^{\mathrm{A}}$ & $39.44^{\mathrm{B}}$ & $62.86^{\mathrm{C}}$ \\
\hline $58^{\prime}$ 's & & & & & \\
56's & & 3.89 & 0.01 & 0.01 & 0.01 \\
50's & & 26.48 & 10.33 & 15.76 & 3.87 \\
48's & & 44.08 & 43.10 & 33.28 & 6.69 \\
\hline $44^{\prime}$ 's & 22.79 & 39.44 & 40.29 & 30.94 \\
\hline
\end{tabular}

$\mathrm{A}, \ldots, \mathrm{D}-\mathrm{P} \leqslant 0.01 ; \mathrm{a}, \mathrm{b}-\mathrm{P} \leqslant 0.05$

group $\mathrm{CxPW}$, followed by Cor before $\mathrm{CxWF}$. The best $(\mathrm{P} \leqslant 0.01)$ staples were found in Cor and $\mathrm{CxEF}$ and the worst in $\mathrm{CxPW}$. The strongest $(\mathrm{P} \leqslant 0.01)$ colour and brilliancy of wool was observed in CxEF and the weakest in Cor. The smallest $(P \leqslant 0.01)$ amount of kemp and medullated fibres was found in $\mathrm{CxEF}$ and $\mathrm{CxF}$ and the highest in $\mathrm{CxPW}$. The best $(\mathrm{P} \leqslant 0.01)$ grease was observed in $\mathrm{CxEF}$ and $\mathrm{CxPW}$. The highest $(\mathrm{P} \leqslant 0.01)$ content of defective crimp was observed in $\mathrm{CxF}$ in comparison with other groups. The general result of fleece estimation is given as a sum of points of every fleece. The CxEF fleeces were found to be best $(\mathrm{P} \leqslant 0.01)$ followed by the control group, $\mathrm{CxF}$ and $\mathrm{CxPW}$. According to the appraisal estimation and the number of fleeces qualified as either upper or lower grade it can be stated that the crossing of Corriedale type ewes with prolific rams lowered the fleece quality of Finnish and Polish „Wrzosówka” rams' daughters. 
TABLE 3

The results of the appraisal estimation of fleeces (points)

\begin{tabular}{|c|c|c|c|c|c|}
\hline Parametr & & Cor & CXEF & $\mathrm{CxF}$ & CxPW \\
\hline Number of fleeces & & 104 & 70 & 71 & 70 \\
\hline Average quality & $\begin{array}{c}\bar{x} \\
S_{E}\end{array}$ & $\begin{array}{r}24.78 \\
0.31\end{array}$ & $\begin{array}{r}25.00 \\
0.17\end{array}$ & $\begin{array}{r}24.97 \\
0.19\end{array}$ & $\begin{array}{r}24.35 \\
0.20\end{array}$ \\
\hline Strength & $\begin{array}{l}\bar{x} \\
S_{\mathrm{t}}\end{array}$ & $\begin{array}{l}4.64^{\mathrm{AB} a} \\
0.15\end{array}$ & $\begin{array}{l}4.74^{\wedge} \\
0.09\end{array}$ & $\begin{array}{l}4.31^{\mathrm{C}} \\
0.09\end{array}$ & $\begin{array}{l}4.38^{\mathrm{BC} b} \\
0.10\end{array}$ \\
\hline Elasticity & $\begin{array}{c}\bar{x} \\
S_{E}\end{array}$ & $\begin{array}{l}3.80^{\mathrm{BCa}} \\
0.14\end{array}$ & $\begin{array}{l}4.06^{\mathrm{A}} \\
0.08\end{array}$ & $\begin{array}{l}4.00^{\mathrm{AB} h} \\
0.09\end{array}$ & $\begin{array}{l}3.72^{\mathrm{C}} \\
0.09\end{array}$ \\
\hline Conformation of length & $\begin{array}{c}\bar{x} \\
S_{E}\end{array}$ & $\begin{array}{l}7.27^{\mathrm{Ba}} \\
0.34\end{array}$ & $\begin{array}{l}7.56^{\mathrm{B}} \\
0.20\end{array}$ & $\begin{array}{l}7.84^{\mathrm{B} h} \\
0.22\end{array}$ & $\begin{array}{l}8.53^{\mathrm{A}} \\
0.22\end{array}$ \\
\hline Stapleness & $\begin{array}{c}\bar{x} \\
S_{\mathrm{E}}\end{array}$ & $\begin{array}{l}8.05^{\mathrm{A}} \\
0.33\end{array}$ & $\begin{array}{l}8.24^{\mathrm{A}} \\
0.19\end{array}$ & $\begin{array}{l}6.71^{\mathrm{B}} \\
0.21\end{array}$ & $\begin{array}{l}5.81^{\mathrm{C}} \\
0.22\end{array}$ \\
\hline Crimpness & $\begin{array}{l}\bar{x} \\
S_{\mathrm{F}}\end{array}$ & $\begin{array}{l}7.98^{\mathrm{BCb}} \\
0.29\end{array}$ & $\begin{array}{l}8.66^{\mathrm{A}} \\
0.17\end{array}$ & $\begin{array}{l}8.16^{\mathrm{AB} a} \\
0.19\end{array}$ & $\begin{array}{l}6.42^{\mathrm{D}} \\
0.19\end{array}$ \\
\hline Colour-brillancy & $\begin{array}{c}\bar{x} \\
S_{E}\end{array}$ & $\begin{array}{l}4.33^{\mathrm{Cd}} \\
0.09\end{array}$ & $\begin{array}{l}4.66^{\mathrm{A} a} \\
0.05\end{array}$ & $\begin{array}{l}4.50^{\mathrm{A} b} \\
0.06\end{array}$ & $\begin{array}{l}4.49^{\mathrm{Bbc}} \\
0.06\end{array}$ \\
\hline $\begin{array}{l}\text { Kemp and medulated } \\
\text { fibres }\end{array}$ & $\begin{array}{l}\bar{x} \\
S_{\mathrm{f}}\end{array}$ & $\begin{array}{l}7.88^{\mathbf{B} a} \\
0.33\end{array}$ & $\begin{array}{l}8.39^{\mathrm{AB} b} \\
0.19\end{array}$ & $\begin{array}{l}8.57^{\mathrm{A}} \\
0.21\end{array}$ & $\begin{array}{l}6.93^{\mathrm{C}} \\
0.21\end{array}$ \\
\hline Grease & $\begin{array}{c}\bar{x} \\
S_{1}\end{array}$ & $\begin{array}{l}3.85^{\mathrm{B}} \\
0.11\end{array}$ & $\begin{array}{l}4.13^{\mathrm{A}} \\
0.07\end{array}$ & $\begin{array}{l}3.83^{\mathrm{B}} \\
0.07\end{array}$ & $\begin{array}{l}4.15^{\mathrm{A}} \\
0.07\end{array}$ \\
\hline Wool yield & $\begin{array}{c}\bar{x} \\
S_{F}\end{array}$ & $\begin{array}{l}2.95^{\mathrm{A}} \\
0.25\end{array}$ & $\begin{array}{l}2.93^{\mathrm{A}} \\
0.14\end{array}$ & $\begin{array}{l}2.22^{C} \\
0.16\end{array}$ & $\begin{array}{l}1.96^{\mathrm{B}} \\
0.16^{2}\end{array}$ \\
\hline Defective crimp & $\begin{array}{c}\bar{x} \\
S_{\mathrm{F}}\end{array}$ & $\begin{array}{l}8.30^{\mathrm{A} b} \\
0.35\end{array}$ & $\begin{array}{l}8.58^{\mathrm{A}} \\
0.20\end{array}$ & $\begin{array}{l}5.87^{\mathbf{B}} \\
0.22\end{array}$ & $\begin{array}{l}8.84^{\mathrm{A} a} \\
0.23\end{array}$ \\
\hline Total points & $\begin{array}{c}\bar{x} \\
S_{E}\end{array}$ & $\begin{array}{c}83.98^{\mathrm{B}} \\
1.14\end{array}$ & $\begin{array}{c}86.94^{\mathrm{A}} \\
0.65\end{array}$ & $\begin{array}{c}80.98^{\mathrm{C}} \\
0.72\end{array}$ & $\begin{array}{c}80.11^{C} \\
0.73\end{array}$ \\
\hline
\end{tabular}

$A, \ldots, D \quad P \leqslant 0.01 ; a, b, c, d \quad P \leqslant 0.05$

The Friesian rams did not decrease the fleece quality and fleeces of their daughters could cause a better impression when compared with Cor.

\section{CONCLUSIONS}

The crossing of Corriedale type ewes with Friesian, Finnish and Polish "Wrzosówka" rams (in comparison with the Cor group) caused a decrease in 
fleece production - the lowest production was noticed in the group CxPW. An increase of staple length and wool thickness was noticed in the group CxPW and a decrease in fleece quality in $\mathrm{CxF}$ and $\mathrm{CxPW}$ groups. The fleeces of $\mathrm{CxEF}$ were classified higher than the fleeces of the Cor group.

\section{REFERENCES}

Borys B., Musiał A., Osikowski M., 1986. Wstępne wyniki użytkowania maciorek pochodzących $\mathrm{z}$ krzyżowania owiec merynosowych z fryzami w systemie 3 stanówki w okresie 2 lat. Zesz. probl. Post. Nauk rol. 303, $111-119$

Borys B., Osikowski M., 1986. Wpływ wczesnego krycia i wykotów maciorek merynosowych i pochodzących z krzyżówek tej rasy 7 trykami rasy fryzyjskiej i owcy olkuskiej na wyniki rozpłodu i produkcję żywca. Zesz. probl. Post. Nauk rol. 303, 119-130

Borys B., Stankiewicz. J., 1986. Wpływ wczesnego krycia i wykotów maciorek merynosowych i mieszańców tej rasy $z$ trykami rasy fryzyjskiej i owcy olkuskicj na ilość i na jakość produkowanej welny. Zesz. probl. Post. Nauk rol. 303, 143-150

Gut A., Kozal E., Grajczak L., 1986. Wydajność rozrodcza i mleczność owicc - mieszańców dwurasowych. Zes7. probl. Podst. Nauk rol. 303, 39-46

Harvey W.R., 1987. User's Guide for LSMLMW Mixed Model Least Squares and Maximum Likelihood Computer Progr. Monogr. Ohio State Univ.

Korman K., Osikowski M., 1986. Produkcyjność maciorek-mieszańców owiec merynosowych $\mathrm{z}$ trykami ras mięsnych, użytkowanych w systemie 3 stanówek w okresie 2 lat. Zesz. probl. Post. Nauk rol. 303, 101-110

Ruszczyc Z., 1981. Metodyka doświadezeń zootechnicznych. PWRiL Warszawa

Ryś R., 1974. Normy żywienia zwierząt. PWRiL Warszawa, 31-50

Skoczylas A., 1963. Wełna krzyżówkowa. Rocz. Nauk rol. Ser. D, 103

Śliwa Z., Kozal E., Gut A., 1983. Produkcyjność maciorek merynosa polskiego i owcy wielkopolskiej oraz ich mieszańców $F_{1}$ po trykach rasy wschodniofryzyjskiej. Zesz. probl. Pods. Nauk rol. 265, $97-102$

Süß R., König K.H., 1984. Die Eigung von fruchtbarkeitsbetonten Kreuzungschafen für die Mastlammerzeugung. 1 Mitteilung: Wolleistung. Arch. Tierzucht, 5, 393-401

Wassmuth R, Jatsch O., 1980. Untersuchungen über Möglichkeiten der Erhohung der Produktivitätszahlen beim Schaf mit Hilfe von Gebrauchskreuzungen. Giessener Schriftenreihe Tierzucht $u$. Haustiergenetik. Ver. P. Parey, Hamburg u. Berlin, 43

\section{STRESZCZENIE}

Wplyw krzyżowania maciorek typu Corriedale z trykami ras plennych na cechy użytkowości welnistej ich potomstwa

W badaniach przeprowadzonych w latach 1982-1989 na 318 maciorkach typu Corriedale i ich mieszańcach $F_{1}$ po trykach ras plennych: wschodniofryzyjskiej owcy mlecznej, owcy fińskiej i wrzosówki polskiej oznaczono cechy masy i wysadności wełny w wieku 12 miesięcy, masę wełny w wieku 2, 3, 4 i 5 lat oraz oceniono organoleptycznie jakość wełny maciorek dwuletnich.

U potomstwa maciorek typu Corriedale skrzyżowanych z trykami ras plennych stwierdzono: - obniżenie produkcji wełny; najniższą masę runa miały mieszańce po trykach wrzosówkowych, 
- zwiększenie wysadności i pogrubienie sortymentu wełny, najwyraźniej zaznaczone u mieszańców po trykach wrzosówki polskiej,

- obniżenie jakości runa u mieszańców po trykach fińskich i Wrzosówkach,

- jakość runa mieszańców po trykach fryzyjskich była nieznacznie lepsza w porównaniu z grupą kontrolną. 